\title{
Immigrant Evangelicalism in the COVID-19 Crisis: Reactions and Responses from Brazilian Evangelical Churches in Florida
}

\author{
Rodrigo Serrão $^{1}$ (D) João Chaves $^{2}$
}

Received: 19 June 2020 / Accepted: 24 August 2020/Published online: 8 September 2020

(C) Springer Nature Switzerland AG 2020

\begin{abstract}
This article seeks to analyze the reactions and responses of three churches of the Brazilian diaspora in Florida, United States, to the COVID-19 pandemic. Drawing on sermons posted on YouTube and Facebook in March, April, and May, we argue that Brazilian immigrant churches in Florida reacted to the pandemic in civil, theological, practical ways. We begin by providing a general introduction to evangelicalism in the United States and its influence in Brazilian evangelical life to give a historically sound background to the study. We also present the story of Brazilian migration to the United States. Then, we analyze the content posted in social media by pastors and churches of the Brazilian diaspora in the United States and other church leaders to ascertain their position regarding the responses to the COVID-19 crisis. Results show the churches responded to the pandemic in three primary ways: they adhered to authorities' guidelines, provided sermons with apocalyptic undertones, and organized food pantries and donations for members in need.
\end{abstract}

Keywords Brazilian diaspora · Evangelical congregations · COVID-19 · Pandemic · Reactions · Florida

Rodrigo Serrão

serrao@hope.edu

João Chaves

joao.chaves@ptsem.edu

1 Department of Sociology and Social Work, Hope College, Van Zoeren Hall, 41 Graves Place, Room 261, Holland, MI 49423, USA

2 Hispanic Theological Initiative, 12 Library Place, Princeton, NJ 08540, USA 


\section{Introduction}

The United States and Brazil share similarities in how their leaders and population reacted to the COVID-19 pandemic. Both US President Donald Trump and Brazilian President Jair Bolsonaro have been under heavy criticism from significant scientific community sectors, liberal media, academic establishment, and the general population for their responses to the global crisis created by COVID-19. Besides, both presidents received strong support from prominent evangelical leaders and significant sectors of the evangelical community. In the United States and Brazil, many evangelical churches rallied behind Trump and Bolsonaro. They supported their message of belittling the danger of the virus and emphasizing the need to open the economy as soon as possible.

At the intersection of American and Brazilian religious life, however, lies a group of communities often overlooked in studies of Latin American religions, namely, the churches of Latin American immigrants who live in the United States. This piece will focus on three Brazilian churches in US soil to assess how they responded to the continuing COVID-19 crisis. More specifically, we are interested in the stance taken by pastors regarding the official positions of government officials, the theological meaning they ascribed to the pandemic, and the economic strains brought by the COVID-19 crisis. As such, our goal is to enhance our understanding of Latin American evangelicalism's political and theological commitments, mainly practiced in a diasporic context. Drawing from a content analysis of sermons posted on social media in March, April, and May, this piece seeks to answer the following question: how have Brazilian immigrant churches in the United States reacted to the policies and rhetoric of Trump, Bolsonaro, state, and local government officials? Also, how have pastors responded to the economic crisis and rising unemployment that followed the pandemic?

This article begins by providing a general introduction to evangelicalism in the United States and its influence in Brazilian evangelical life to give a historically sound background to the study. In this first section, we will also focus on the little known story of Brazilian migration to the United States. We will analyze the content posted in social media by pastors of churches of the Brazilian diaspora in the United States, to ascertain their responses to the COVID-19 crisis. Finally, we will conclude by connecting some general theological tropes, specifically apocalypticism, to the immigrant churches' answers presented in the study.

\section{Brazilian Immigrant Evangelicalism: a Transnational Historical Sketch}

The terms "evangelical" and "evangelicalism" are themselves multifaceted, and their usage varies in both Brazil and the United States (Chaves 2013). For this piece, the term "evangelicalism" will describe the pietistic-revivalist form of American Christianity that began to take shape in the middle of the eighteenth century, during the period known as the First Great Awakening. Such a period inhabited the religious dispositions that reacted against the perceived threat of the Enlightenment in the nineteenth century. Additionally, it manifested itself in both Northern and Southern fundamentalisms and the mostly White Christian conservatism organized in the 1930s and 1940s continues to influence global religion and politics today. As such, this piece takes a long view of evangelicalism and includes in its usage the term "evangelical" all and any conservative 
Christian group that expresses the characteristics described by David Bebbington in his classical study of the movement, namely, biblicism, crucicentrism, conversionism, and activism (Bebbington 1989). Evangelical, from this perspective, is "an umbrella term for conservative Christians in American culture" (Wellman 2008) as well as the global adherents of the evangelical movement (Stanley 2013).

In Brazil, the term "evangelical" is often used as a synonym to "protestant," which complicates further the accuracy of the term (Rabuske et al. 2012). The theological and political overlaps between US White evangelicals and Brazilian protestants in general, however, are strong enough to warrant a qualified use of the term "evangelical" as an appropriate descriptor of both conservative Christians in the United States and Brazilian popular Protestantism. For example, Freston singled out Brazil as the only Latin American country in which what he called "Historical Protestantism" achieved a measure of success even in light of the explosive growth of Pentecostalism (Freston 2008a). However, this US evangelical influence transcends denominational lines as well as traditional/Pentecostal/Charismatic lines. The ideological overlap between US and Brazilian evangelicals is not coincidental. Throughout the history of the long evangelical movement, Brazilian evangelicalism not only begun as a result of US evangelical missionary efforts, but the influx of US evangelical influence in Brazil has been sustained by direct missionary involvement, US-based control of Brazilian institutions of cultural productions (seminaries, religious periodicals, publication houses, etc.), uneven partnerships between US and Brazilian evangelical churches, and the flow of information through modern and contemporary technologies (Garmany and Gerhardt 2015; Chaves 2020).

In term of the histories of Brazilian Protestantism, it is of especial concern that the churches that will be dealt with here are Baptist and Pentecostal, and it was precisely in the history of Southern Baptist missions that the genesis of both Baptists and Pentecostals converge in Brazil (Alencar 2013; Premack 2011). The multifaceted and polymorphous history of US and Brazilian evangelicalisms is undoubtedly filled with several noteworthy exceptions to US-based conservative commitments. However, their respective theopolitical conservatism was a result of the transnational dissemination of ideas and projects that often carried the formulations, theologies, social imaginations, and political dispositions of the US evangelical religious establishment (Mesquida 1994; Alencar 2007; Anjos and Carvalho 2017). Today, both the United States and Brazil are living the manifestations of an evangelicalism forged as a theologically conservative, mostly White-led movement whose contemporary identity in the United States was partially formed as a reaction to the changes brought by the Civil Rights Movement as well as by movements for reproductive rights and gender equality (Bean 2014; Brown 2019; Wong 2018; Wuthnow 1989; Tisby 2020; Jones 2020). The broad support that evangelicals give to Donald Trump in the United States and Jair Bolsonaro in Brazil is partially a result of a continuous process or globalization of US evangelicalism.

For this study, it is essential to note the transnational influence of US evangelicalism in Brazil. It is to the evangelical churches of the Brazilian diaspora that this piece turns its gaze. Even though many studies deal with the history of US evangelicalism and Brazilian evangelicalism in Brazil, the history of the churches of the Brazilian diaspora in the United States is still understudied. The story of the churches of the Brazilian diaspora begins with the history of Brazilian immigration to the United States, which 
influenced the creation of several Brazilian immigrant churches in the country (Chaves 2017; Freston 2008b; Rodrigues 2012; Rodrigues 2016; Serrao and Cavendish 2018).

The United States is the preferred destination for Latina/o immigrants in general and Brazilians in particular. There are more Brazilians in the United States than in all the other destinations for Brazilian immigrants combined (Margolis 2013). Individual Brazilians have come to the United States for over a century, but the most recent Brazilian migration waves began in the 1980s (Cebulko 2013). The first Brazilian communities in the United States may date back to the 1960s, when there were already Brazilian groups in New York, New Jersey, Boston, and California. It was in the 1980s, however, that people from the town of Governador Valadares began migrating by using the avenues opened to them by the Boston engineers who had lived in the city during the WWII when they went to Brazil to build railroads and work in the mining industry (Margolis 2009). In the 1980s, Brazil was undergoing a severe economic crisis, and inflation was a significant drawback for middle-class families. During this period, Brazilians who migrated to the United States had access to the information and the financial means necessary for the trip.

The Brazilians who ended up making their way to New York City, for instance, were middle-class, well educated, and light-skinned, giving further evidence to the case that group migrations usually begin with upper classes that blaze the trail and establish international networks that later facilitate the movement of the lower classes (Margolis 2013). According to Ana Cristina Braga Martes, if one had to trace a profile of the typical Brazilian in the United States, one would have to say that he or she is in their mid-thirties, married, living with spouse and children, is from the state of Minas Gerais, and came to the United States looking for better job opportunities (Martes 2011). In the case of Brazilians, however, the search for new job opportunities must be primarily understood not as a search for survival, but as a dream of consumption. Brazilians in general and middle- and upper-class Brazilians, in particular, are generally beholden to US culture and products. This Brazilian appreciation of an imagined United States also has historical roots. The spread of the intentional dissemination of the ideal of the United States' greatness in Brazil can be traced back to the 1940s. During the WWII, the United States began what historian Antonio Tota calls "a game of seduction" to diminish European influence in the country and augment the appreciation for US culture (Tota 2009). The strategy worked so well that a few decades later, middleand upper-class Brazilians would be enamored with US culture and products, and some would do whatever they could to obtain the dollars that could buy them such thingseven if they had to leave their country.

New England and New York were ideal destinations for Brazilians in the 1980s, not only because of the economic boom in these regions or because of the Brazilian-US networks that facilitated the migration, but also because of the Portuguese-speaking populations in the area, who came primarily from Portugal, Azores, and Cape Verde (Debiaggi 2001). In this region, the vast majority of Brazilians initially settled, although today there are Brazilian enclaves in many major US cities. Since the initial wave of Brazilian migration in the 1980s, there was a second wave in the late 1990s. Since then, most sociological works indicate that the new Brazilian immigrants are more representative of the Brazilian population than those who came in the first wave. Between 2002 and 2012, due to the economic growth that happened during the government of the Workers' Party in Brazil, Brazilian migration to the United States diminished 
considerably. Since 2012, however, the country's economic growth has stagnated, and new waves of Brazilian immigrants began migrating to the United States.

Although there are less than two million Brazilians in the United States, an awareness that Brazilian presence in the US religious market goes beyond a sheer body count is vital for scholars concerned with the relationship between religion and globalization (Lima and Castro 2017). The Universal Church of the Kingdom of God (UCKG), for example, has over one hundred churches in the United States alone, and many times, only the pastor of these congregations is Brazilian. The UCKG is only one of many neo-Pentecostal denominations successfully exporting its product to the United States. Beyond Christian boundaries, a quick Google search will provide information on where English-speaking seekers can attend Candomble, Xango, Umbanda, and Santo Daime services, to name a few religions of Brazilian origins. In short, in the US religious market, Brazilian representation surpasses, by far, the number of Brazilians.

It is widely recognized that many Latin American and African Charismatic churches have created robust global networks and are energizing the religious landscapes in Europe and the United States (Jenkins 2007; Leonard et al. 2006; Levitt 2007; Portes and Rumbaut 2014). But within this dynamic, Brazil seems to be somewhat unique. Manuel Vasquez and Cristina Rocha argue that there are two main reasons for the appeal of Brazilian religions: (1) the attempt on non-Brazilians to consume an imagined projection of Brazilian culture and (2) the aggressiveness and creativity of Brazilian religious entrepreneurs (Vasquez and Rocha 2013). The particular case of Brazilian religious representation and appropriation points to the need to abandon old assumptions in which the nation-state is the locus of religious activity and to appropriate an approach that recognizes that religious authority, authenticity, piety, and practice are also negotiated across borders (Bender et al. 2012; Cavalcanti 2012; Corten and Marshall-Fratani 2001). In the words of Peggy Levitt, "American Religious life is no longer just American;" developments in the home country may affect immigrant religious communities as much as the structural realities they face in the host country (Levitt 2007). But the structure of the host country is also essential. Although immigrants may, in their religious meetings in the United States, act - as they often do - as if they were in a different space, the porosity of immigrant life prohibits sharp isolation of foreignness from the exigencies of the host country.

It is from within this broader, fluid, and complex context of migration that the churches of the Brazilian diaspora form in the United States. The makeup of the churches of the Brazilian diasporas is diverse, and many churches adapt to demographic changes. Chaves' socio-historical work with Brazilian Baptist churches in the United States, for example, suggests that many Brazilian immigrant churches cater to people from several Latin American backgrounds as well as White Americans (Chaves 2017, see also Serrao 2020). Therefore, a study of Brazilian immigrant evangelical churches offers a much-needed analysis of the religious life of this critical ethno-racial group and provides a more general look at immigrant religious life in America. In this broader sense, the COVID-19 pandemic, considering the strong support given to Trump by White evangelicals and the evangelical support for Bolsonaro in Brazil, postulates a particularly unique opportunity to look at the behavior of the churches of Latin American immigrants in the United States concerning their historical commitment to right-wing conservatism. However, in the case of evangelical support for Bolsonaro, it is important 
to mention that issues related to the perceived corruption of the previous administration and initiatives of gender inclusion were central to evangelical political affiliation and voting patterns.

\section{Immigrant Churches and COVID-19}

\section{Methods}

During the COVID-19 pandemic, churches have been important sites of response to government guidelines and regulations. Already in March of 2020, due to national, state, and local guidelines for reducing large gatherings through the implementation of social (physical) distancing directives, many houses of worship decided to have their services live-streamed online (Volz 2020). Brazilian evangelical immigrant congregations had to adapt to this new reality as a collective effort to "flatten the curve." Here, we analyze three Brazilian immigrant congregations' reaction and adaptation to the COVID-19 pandemic.

We use a purposive sampling approach in our choice of these congregations. As a non-probability sampling technique, we selected the congregations that best fit the purpose of our investigation. Our goal was to seek congregations of different denominations that catered to a Brazilian audience, used various online tools to reach out to their membership, and were located in different urban areas within the state of Florida. As such, this article centers its analyses on three congregations distributed equally in North, Central, and South Florida, the state with the largest Brazilian immigrant community in the United States (Blizzard and Batalova 2019).

In total, this piece analyzes 57 online religious meetings that the congregations posted during March, April, and May in two social media platforms: Facebook and YouTube. These congregations maintained their regular Wednesday and Sunday services (with the participation of several other people, like the music team) and added the pastors' weekly and, in the case of the Central Florida congregation, daily "live" meetings. Such events, called just as "lives," did not exist before the pandemic and were possibly created to, among other things, keep congregants engaged with the church.

Reactions to the pandemic varied among congregations. Because these congregations are interested in their members' well-being and because of the current US administration's strict stance on immigration, we anticipate that the congregations would follow government guidelines with minimal criticism. However, such compliance did not prevent churches to creatively criticize some decisions taken by local government officials to contain the spread of the virus.

In the next section, we turn to an analysis of the congregations' reactions and responses to the COVID-19 pandemic in a reality in which technology became the primary means through which pastoral care and communal gatherings were operationalized. As time progressed, online religious services became the "new normal" in the adaptation of congregational life to the extent that churches are already thinking about how this pandemic will permanently affect their modus operandi. Even though these services were recorded, posted on social media, and available for anyone to access, we used pseudonyms to protect the congregations and their members' identities. 


\section{Engaging Membership Through Online Services}

The three churches investigated here engaged their membership and did online services differently. Both Central and South Florida churches continued to hold services in the church building with a reduced number of people. They held live services via YouTube (South Florida) and Facebook (Central and South Florida) with those in the music team playing and singing without masks. In fact, on April 19, the South Florida congregation had 15 people on stage among singers and musicians, and none wore masks. The Central and South Florida congregations also promoted "drive-in" services. These services allowed members to watch the sermon from their cars parked in the churches' parking lot.

Differently, the North Florida congregation decided to use Facebook's "Messenger Rooms" app, where each church member who participated in the service was invited by the pastor who directed the service from his dinner table. This model varied significantly from the other two churches. Even the singers participated in the service from their homes. Additionally, the North Florida church's casual format allowed them to be much more interactive with their live audience than the Central and South Florida congregations. All three churches, however, took advantage of the online format to address people in Brazil. In terms of "views," all three churches had some of their services watched by thousands of people and shared hundreds of times. One single video of the North Florida congregation had more than 3700 views on this article's writing.

Below, we analyze three immediate responses to the COVID-19 pandemic taken by the congregations.

\section{Addressing Their Obedience to Authorities}

One crucial point that leaders wanted to convey to their congregants was that they were following the authorities. Even though many states in the United States, including Florida, placed houses of worship on the list of essential services (Villa 2020), thus exempting them from social distancing norms, the three Brazilian congregations decided to suspend all face-to-face services. Such a decision was aligned with the Centers for Disease Control and Prevention (CDC) recommendations to "consider cancelling gatherings of more than 10 people" (CDC 2020). In fact, except for the congregation in Central Florida, which explicitly mentioned the lack of prohibition by state authorities, the other two congregations only referred to their obedience to authorities as to the reason for moving their services online. The pastor of the Central Florida congregation even said during a sermon on March 18 that if members showed up in front of their building, they would let them get inside "until we have the maximum number that the government has suggested." This number, according to the pastor, was 50 people.

Nonetheless, he was aware of how fluid the situation was at the time. He continued, "Everything can change tomorrow. It is possible that tomorrow they [government] come and say, 'we suggest no more than ten, or even five as Trump had also suggested some days ago." Some of the guidance used by the Central Florida pastor to inform his congregation came through his meetings via an open telephone channel that was exclusive for religious leaders. According to the pastor, such encounters included "Florida's governor and senator, as well as the president and vice-president." 
The leaders of the North and South Florida congregations emphasized the government's decision to restrict large gatherings and their obedience to authorities. The North Florida pastor, however, recognized in a sermon broadcasted on March 29 that "if authorities [...] did not prohibit services, the church would be full of people worshiping..." The pastor in South Florida also mentioned that "government or any other agency that is ahead of health issues in the U.S." was essential to determine when they would resume their face-to-face services. Such reactions by the three Brazilian evangelical immigrant congregations, although aligned with most of the churches in the United States, contrasted drastically with some congregations that defied stay-at-home orders (Luscombe 2020) and continued to have in-person services, regardless of the possibility of widespread contamination (Shin, Berkowitz, and Kim 2020).

\section{Criticizing Authorities}

However, obedience to authorities did not translate in a complete lack of criticism of the government. Different from how a US pastor from a large congregation in Florida who called local authorities "tyrannical government" (Deese 2020), Brazilian pastors criticized the government in more nuanced ways. For instance, in March 29 during a conversation between the lead pastor and his co-pastor posted on Facebook, the copastor of the North Florida congregation blamed the pandemic on "God's hand" because of the government's "changing marriage laws," to new laws that were against "biblical principles." The pastor directed his comment to the United States Supreme Court's decision in Obergefell v. Hodges's case, which ruled that same-sex marriage was legitimate and constitutional. For this pastor, God used the pandemic to punish the nations due to a single country's decision. Such a narrow perspective appeared in different ways in all three churches that believed the pandemic was a way God punishes an unrepentant church.

On April 11, the South Florida pastor criticized the government during a "live" event posted by the pastor on YouTube. He complained about the local police's decision to restrict their drive-through, food donation activities. After explaining one of their successful food donation efforts, the pastor said:

"[b]ut then, we got a call from the local police chief saying that we couldn't do this [donation] because we had to pay for the space we used, the police that came here and they [local authority] wanted to stop us."

"We are a church founded by immigrants," continued the pastor, "and what are we doing? We want to bless this country [...] we are not here to do something to our benefit," he concluded in a frustrated tone.

Finally, on April 15, the pastor of the Central Florida congregation, probably the most politically engaged of the three, delivered an entire sermon about potential government interference in the church. When I watched this sermon, it was viewed more than 800 times and shared 14 times. What is particularly relevant about this sermon is that the pastor preached it on the week that the local government declared a curfew from $9 \mathrm{pm}$ to $5 \mathrm{am}$. The pastor used the book of Daniel, Chapter 3, where Babylon's King, Nebuchadnezzar, ordered his servants 
to build a golden image to be worshipped by the people every time they heard the sound of music instruments (horn, pipe, lyre, etc.). According to the biblical text, whoever did not bow down to worship the image made by the king should be thrown into a blazing furnace. After explaining the passage, the pastor decided to apply Daniel 3 to his congregation by saying:

God is the only one who can stop us. We are facing uncertainties [...], we are facing decrees that are imposed by government officials who say it must be this way, it must be that way. Pay attention; these are evil strategies of Satan, who is the figure of Nebuchadnezzar.

He then continued:

We don't know what is in store for us in the future. What awaits us ahead. What the next decrees are. What the prohibitions set by the government are.

Again, distinct from some US pastors and Catholic priests who defied state orders to suspend services (Gjelten 2020), the Central Florida pastor did not want to be understood as someone incentivizing members disobey government authorities. He said:

Pastor, are you saying then that we should go against the government? I am not saying this. What I'm saying is that there may come a time when some ideologies that will be taught by some authorities, they will confront the truth of God's word, and then I ask you, what are you and I going to do?

Even though the pastor did not mention the curfew directly, he probably had the political polarization in which both Brazil and the United States are immersed in mind (Boito 2018; Martí 2019). As such, his sermon spread mistrust in the government, particularly left-leaning ones. His reference to ideology can also point to recent discussions in Brazil about "gender ideology."

To understand this confusion, it suffices to say that sexuality issues have generated misinterpretation and prejudice in Brazil, mainly in religious circles. As a result, politicians have co-opted the more conservative sectors of the Evangelical and Catholic churches, taking advantage of the deep political divisions between left- and right-wing politics worldwide (Miskolci and Campana 2017). The Brazilian President Jair Bolsonaro was propelled to the national spotlight after his racist, sexist, xenophobic, and homophobic comments.

However, during his tenure as a congressman, it was his clash with feminists and supporters of the so-called gender ideology (Henrique 2018) that gave him access to and the sympathy of the religiously conservative sectors in Brazil. Evangelicals became an influential force, including those who had migrated to other countries. According to reports from a Brazilian news agency (Moreno 2018), in the 2018 presidential election, Bolsonaro won in all eight US cities that offered ballots for Brazilian immigrants to vote.

In addition to this initial reaction, the congregations also had something else in common. They all pursued the same theological theme during their initial sermons: God sent the pandemic to bring forth repentance and the world to an end. 


\section{Providing an Apocalyptic Message}

Most of the sermons during the beginning of the quarantine addressed the pandemic in one way or another. While members were encouraged by their leaders to take advantage of their time at home to be more involved with their families, pastors were providing spiritual explanations by framing the COVID-19 pandemic as the "beginning of the end" of the world. On March 27, in a "live" event held by pastors of the Central Florida congregation, they mentioned God was displeased with Brazil, Europe, and the United States, in part, because these places had removed God from schools, mocked Jesus during Carnival celebrations, and had become atheists. She then asked, "did the plague come to kill or to cause a change?"

On a live-streamed video on March 29, the North Florida pastor demonstrated his surprise in one sermon when he said, "I have never seen anything like this, all churches around the world stopping their in-person services." He then continued: "The church has to accept that it is God Himself, leading us into the desert. There is a purpose in that. [...]"

The idea that God is preparing the church for the end of times was common among the leaders of these congregations. In South Florida, the pastor believed that the race for a cure was to be understood as a prophetic act that could lead to the rise of a global leader. He said:

There is something prophetic happening; there is something ... brothers don't be deluded; this is not natural. The whole world is surrendering to something. The entire world wants someone to bring a solution to this problem. I want to tell you, you need to be discerning what the word of God says. Beware, there is already [something] great [happening] in the spiritual world. A savior who comes to solve the problem of the whole world? Be careful!

Here, the pastor referred to the commonly held idea that the antichrist is going to be a charismatic world leader that will bring peace and stability to humanity in times of crisis. The pastor in North Florida also believed that the Bible had foreseen the 2020 pandemic. He said, "the things that are happening today were prophesied by our parents, by the prophets, many years ago..." Finally, in Central Florida, the pastor believed that even if the virus was "created by men," God "allowed" that to happen.

Such messages, loaded with apocalyptic connotations, accomplish at least two goals for these immigrant congregations. First, they orient immigrants' perception of current world events by placing their faith at the center of history. But most importantly, they help immigrants cope with their suffering in a context of political, social, economic, and public health uncertainties. Nonetheless, congregations did not respond to the pandemic only by providing theological explanations, but also by acting in practical ways.

\section{Addressing the Economic Crisis}

Pastors also addressed the rise of unemployment and the economic crisis brought by the pandemic. For instance, on March 27, the Central Florida pastor referred to the more than 3 million people who filed for unemployment that week in the United Stayes, but 
then added "we give glory to God because most of us here at the church is employed. We have our jobs; we have our livelihood, which is really a very good thing." However, on April 8, this same pastor asked for food donations because "there are many families in need. We hardly have a day here in the church when a family or two do not come to knock on our door and ask, 'do you have food to give us?"' As a result of the quick rise of unemployment and financial need among members of the Central Florida congregation, the leadership decided to organize a food pantry and donate " 100 food baskets." The North Florida pastor emphasized how the church members were helping each other. "We know of brothers who are collaborating in the community. And others are giving food to each other. There was a sister who had a baby, and a brother delivered food straight to her door [...] [I knew of] a brother who gave work to another [member], and together we are winning." In South Florida, the church held a drive-through where they donated "eggs, milk, chicken, fish, fruits, and vegetables" to more than "600 families" on Thursdays and Saturdays.

The situation for undocumented immigrants in these churches was even more alarming since they did not qualify for the federal government's stimulus check (CARES Act) like most US citizens did. Considering that a large percentage of the Brazilian immigrant population is undocumented (Margolis 2013) and that most Brazilian immigrants work in the service sector-like house cleaners, construction workers, etc. - or are small business owners (Martes and Rodriguez 2004), members may have struggled financially during the pandemic.

However, despite the financial need that some members were going through, the churches continued to ask for monetary donations. For instance, one pastor at South Florida said:

... maybe today, you're in need. But you know, perhaps the little that you have can bless another. [You may say] but pastor, I have received so little. Maybe the few that you have can bless someone. God can multiply that seed.

Similarly, to their parishioners, churches also have been struggling financially during this pandemic. Online services are not as effective as in-person meetings when it comes to collecting tithes and offerings. Therefore, the COVID-19 pandemic pressured religious leaders to navigate the conundrum of trying to be pastoral and sympathetic to their parishioners' financial struggles and facilitating the economic feasibility of the religious institution on the other.

\section{Discussion/Conclusion}

In this article, we examined the responses and reactions of Brazilian immigrant congregations located in North, Central, and South Florida to the COVID-19 pandemic. The way in which the Brazilian immigrant churches positioned themselves vis-a-vis local authorities points to their obedience to official guidelines and regulations. However, this obedience was characterized by an apocalyptic theological imagination that interpreted both the pandemic and governmental restrictions as punishments for behaviors that were seen as immoral and offensive to God. In addition, churches attempted to balance sympathy for their parishioners' financial struggles with the 
community's own financial needs. Based on these findings, it is clear that Brazilian churches followed in the theological footsteps of their US-informed evangelism while simultaneously making clear to their parishioners-many of whom are undocumented - that they were not inciting any form of disobedience to governmental regulations. This obedience, however, was primarily informed by issues of immigration status, not theological disposition.

Apocalypticism has been a central and continuous theme of evangelical theology from its inception until today. Although, in some evangelical corners in the United States, apocalyptic language has recently lost its central role, the Southern Hemisphere's evangelicalism embraced the apocalyptic language of US evangelicals. As historian Matthew Sutton asserts, "While evangelicals' apocalyptic convictions have waned somewhat in the United States, the belief that the end is nigh is rapidly spreading through the Southern Hemisphere" (Sutton 2014). However, Sutton did not pay enough attention because apocalyptic evangelicals from the Southern Hemisphere now worship in immigrant churches all across the United States. The apocalyptic disposition of evangelicalism is, as evangelicalism itself, a global phenomenon. The influx of evangelicals from the Southern Hemisphere to the United States (and Europe), in turn, may point to ways in which the apocalyptic theological commitments of evangelicals are also maintained through South-North migration. The messages of Brazilian immigrant churches during the COVID-19 crisis point firmly in the direction of US-inspired evangelical apocalypticism.

In terms of the responses Brazilian evangelicals in Brazil have given to the COVID19 pandemic, it is essential to point out that Brazilian evangelicals are diverse. However, evangelicals in Brazil are more likely to be against governmental regulations than the general population (Mori 2020). Apocalypticism on the part of Brazilian evangelicals in Brazil was also prominent among religious leaders in general and Pentecostal leaders in particular. Edir Macedo, for example, attributed the pandemic to Satan (MSN 2020). Prominent evangelical leaders such as Silas Malafaia, R.R. Soares, Valdomiro Santiago, and Estevam Hernandes, among others, position themselves firmly against public health authorities in Brazil (Fiorotti 2020). A significant number of evangelicals in the United States did the same, with some churches going as far as suing the government to defy shutdowns (Rowan 2020). Finding themselves at the intersection of Brazil and the United States, Brazilian churches in the United States responded in continuity with their US and Brazilian evangelical counterparts while making sure that their members follow the law, given their status as immigrants.

Our analysis only considered the messages posted online during March, April, and May of 2020. Even though the state of Florida has loosened its restrictions, and the CDC has provided guidelines for houses of worship to return their services, the congregations analyzed here are still broadcasting some services online. The responses we highlighted provide a window into the range of other experiences and reactions houses of worship (particularly immigrant congregations) have during this time. As the pandemic continues to affect society in profound ways, including exposing systemic racism and oppression embedded in the US and Brazilian societies, it is vital to investigate how congregations support their most vulnerable members while also being co-participants in colorblind racism (Hearn 2009; Bonilla-Silva 2006; Serrao 2020). Future studies should focus on how and to what extent Brazilian immigrant congregations address broader conversations around issues of race and racism in the United States. 
Authors' contributions The authors contributed equally to the conception of the idea, to the design and implementation of the research, to the analysis of the results, and the writing of the manuscript.

Funding The authors received no specific funding for this work.

\section{Compliance with ethical standards}

Conflict of interest The authors declare that they have no conflict of interest.

\section{References}

Alencar G (2007) Protestantismo Tupiniquim. Aret Editorial, São Paulo

Alencar G (2013) Matriz Pentecostal Brasileira: Assembleias de Deus, 1911-2011. Novos Dialogos, Rio de Janeiro

Anjos ML, Carvalho CH (2017) Ações Educacionais dos Missionários Batistas Norte-Americanos no Início do Século XX no Brasil. In: Vieira, CRA, Nascimento EFVBC (eds) Contribuições do Protestantismo para a História da Educação no Brasil e em Portugal. UNIMEP, Piracicaba, pp 207-232

Bean L (2014) The politics of evangelical identity: local churches and partisan divides in the United States and Canada. Princeton University Press, Princeton

Bebbington DW (1989) Evangelicalism in modern Britain: a history from the 1730s to the 1980s. Routledge, London

Bender C, Cadge W, Levitt P, Smilde D (eds) (2012) Religion on the edge: de-centering and re-centering the sociology of religion. Oxford University Press, New York

Blizzard B, Batalova J (2019) Brazilian immigrants in the United States. Migration Policy Institute 23 January 2020. https:/www.migrationpolicy.org/article/brazilian-immigrants-united-states

Boito A Jr (2018) Reforma e crise política no Brasil: Os conflitos de classe nos governos do PT. Editora Unicamp, Campinas

Bonilla-Silva E (2006) Racism without racists: color-blind racism and the persistence of racial inequality in the United States, 2nd edn. Rowman \& Littlefield Publishers, Lanham

Brown JA (2019) White Christianity and resistance to civil rights for racial minorities in twenty-first-century America. In: Gorman JL, Childers JW, Hamilton MW (eds) Slavery's long shadow: race and reconciliation in American Christianity. Eerdmans, Grand Rapids, pp 109-129

Cavalcanti HB (2012) Almost home a Brazilian American's reflections on faith, culture, and immigration. The University of Wisconsin Press, Madison

CDC (2020) Florida community mitigation - coronavirus disease 2019 (COVID-19). In: Centers for Disease Control and Prevention. Available via CDC. https://www.cdc.gov/coronavirus/2019-ncov/casesupdates/florida.html. Accessed 12 June 2020

Cebulko KB (2013) Documented, undocumented, and something else: the incorporation of children of Brazilian immigrants. LFB Scholarly Pub, El Paso

Chaves JB (2013) Evangelicals and liberation revisited: an inquiry into the possibility of an evangelicalliberationist theology. Wipf \& Stock Publishing, Eugene

Chaves JB (2017) Disrespecting borders for Jesus, power, and cash: Southern Baptist missions, the new immigration, and the churches of the Brazilian diaspora. Ph.D. Diss., Baylor University

Chaves JB (2020) O Racismo na História Batista Brasileira: Uma Memória Inconveniente do Legado Missionário. Novos Diálogos, Brasília

Corten A, Marshall-Fratani RR (2001) Introduction. In: Corten A, Marshall-Fratani RR (eds) Between Babel and Pentecost: transnational Pentecostalism in Africa and Latin America. Indiana University Press, Bloomington, pp 1-21

Debiaggi SDD (2001) Changing gender roles: Brazilian immigrant families in the U.S. LFB Scholarly Publishing, New York

Deese K (2020) Florida megachurch pastor says he's closing church due to 'tyrannical government.' TheHill. 12 June 2020. https://thehill.com/homenews/news/490789-florida-megachurch-pastor-says-hes-closingchurch-due-to-tyrannical-government

Fiorotti S (2020) Liberdade religiosa dos evangélicos em tempos de pandemia. A Pátria. https://apatria. org/politica/liberdade-religiosa-dos-evangelicos-em-tempos-de-pandemia/. Accessed 17 June 2020 
Freston P (ed) (2008a) Evangelical Christianity and democracy in Latin America. Oxford University Press, Oxford

Freston P (2008b) The religious field among Brazilians in the United States. In: Jouët-Pastré C, Braga LJ (eds) Becoming Brazuca: Brazilian immigration to the United States. Harvard University Press, Cambridge, pp 255-268

Garmany J, Gerhardt H (2015) Global networks and the emergent sites of contemporary evangelicalism in Brazil. In: Brunn SD (ed) The changing world religion map: sacred places, identities, practices and politics. Springer, New York, pp 2011-2024

Gjelten T (2020) Some religious leaders vow to have in-person services despite government orders. NPR. 13 June 2020. https://www.npr.org/2020/05/22/861202454/some-religious-leaders-vow-to-have-in-personservices-despite-government-orders

Hearn M (2009) Color-blind racism, color-blind theology, and church practices. Relig Educ 104(3):272-288

Henrique G (2018) 'Ideologia de gênero' é o que mais mobiliza eleitor evangélico. DW 5 December 2018. https://amp.dw.com/pt-br/ideologia-de-g\%C3\%AAnero-\%C3\%A9-o-que-mais-mobiliza-eleitorevang\% $3 \%$ A 9 lico/a-45964108

Jenkins P (2007) The next Christendom: the coming of global Christianity. Oxford University Press, Oxford Jones RP (2020) White too long: the legacy of white supremacy in American Christianity. Simon \& Schuster, New York

Leonard KI, Stepick A, Vasquez MA, Holdaway J (2006) Immigrant faiths: transforming religious life in America. AltaMira Press, Walnut Creek

Levitt P (2007) God needs no passport: immigrants and the changing American religious landscape. The New Press, New York

Lima AEC, Castro ALB (2017) Brasileiros nos Estados Unidos: Meio século (re)fazendo a América (19602010). Fundação Alexandre de Gusmão, Brasília

Luscombe R (2020) The US churches and pastors ignoring 'stay-at-home' orders." The Guardian. 11 June 2020. http://www.theguardian.com/world/2020/apr/05/coronavirus-churches-florida-socialdistancing

Margolis ML (2009) An invisible minority: Brazilians in New York City. University Press of Florida, Gainesville

Margolis ML (2013) Goodbye, Brazil: Émigrés from the land of soccer and samba. University of Wisconsin Press, Madison

Martes ACB (2011) New immigrants, new land: a study of Brazilians in Massachusetts. University Press of Florida, Gainesville

Martes ACB, Rodriguez CL (2004) Afiliação religiosa e empreendedorismo étnico: O caso dos Brasileiros nos Estados Unidos. Rev Adm Contemp 8(3):117-140

Martí G (2019) The unexpected orthodoxy of Donald J. Trump: White evangelical support for the 45th President of the United States. Sociol Relig 80(1):1-8

Mesquida P (1994) Hegemonia norte-americana e educacão Protestante no Brasil: um estudo de caso. Editora da Facultade de Teologia da Igreja Metodista, Juiz de Fora

Miskolci R, Campana M (2017) 'Ideologia de gênero': notas para a genealogia de um pânico moral contemporâneo. Soc Estado 32(3):725-748

Moreno AC (2018) Bolsonaro vence nos EUA, Venezuela, Israel e Irã; Ciro, em Berlim, Paris e Pequim; Haddad, na Palestina, Cuba e Nigéria. G1. 29 May 2019. https://g1.globo.com/politica/eleicoes/2018 /eleicao-em-numeros/noticia/2018/10/07/bolsonaro-vence-nos-eua-venezuela-israel-e-ira-ciro-em-berlimparis-e-pequim-haddad-na-palestina-cuba-e-nigeria.ghtml

Mori L (2020) Crise de coronavírus expõe racha entre evangélicos no Brasil. BBC News Brasil 28 April 2020. https://www.bbc.com/portuguese/brasil-52313890

MSN (2020) Edir Macedo atribui pandemia a 'Satanás' e fala em 'interesses econômicos.' 17 June 2020. https://www.msn.com/pt-br/noticias/brasil/edir-macedo-dissemina-informa\%C3\%A7\%C3\%B5es-falsase-atribui-coronav\%C3\%ADrus-a-\%E2\%80\%9Csatan\%C3\%A1s\%E2\%80\%9D/ar-BB11ehin

Portes A, Rumbaut RG (2014) Immigrant America: a portrait. University of California Press, Berkeley

Premack L (2011) 'The Holy Rollers are invading our territory': Southern Baptist missionaries and the early years of Pentecostalism in Brazil. J Relig Hist 35(1):1-23

Rabuske JI, Santos PL, Gonçalves HA, Treib L (2012) Evangélicos Brasileiros: quem são, de onde vieram e no que acreditam? Rev Bras Hist Relig 12:255-267

Rodrigues D (2012) The Brazilianization of New York City: Brazilian immigrants and Evangelical churches in a pluralized urban landscape. In: Cimino R, Mian NA, Huang W (eds) Ecologies of faith in New York City: the evolution of religious institutions. Indiana University Press, Bloomington, pp 120-141 
Rodrigues D (2016) O Evangélico imigrante: O Pentecostalismo Brasileiro salvando a América. Fonte Editorial, São Paulo

Rowan N (2020) Evangelicals drive religious liberty battle over pandemic shutdowns. Washington Examiner, 17 May 2020. https:/www.washingtonexaminer.com/news/evangelicals-drive-religious-liberty-battleover-pandemic-shutdowns

Serrao R (2020) Winning 'Americans' for Jesus?: second-generation, racial ideology, and the future of the Brazilian Evangelical church in the U.S. Ph.D. Diss, the University of South Florida

Serrao R, Cavendish J (2018) The social functions and dysfunctions of Brazilian immigrant congregations in 'Terra Incognita'. Rev Relig Res 60(3):367-388

Shin Y, Berkowitz B, Kim MJ (2020) How a South Korean church helped fuel the spread of the coronavirus. Washington Post 12 June 2020. https:/www.washingtonpost.com/graphics/2020/world/coronavirussouth-korea-church/

Stanley B (2013) The global diffusion of evangelicalism: the age of Billy Graham and John Stott. IVP Academic, Downers Grove

Sutton MA (2014) American apocalypse: a history of modern evangelicalism. Belknap Press, Cambridge

Tisby J (2020) The color of compromise: the truth about the American Church's complicity in racism. Zondervan, Grand Rapids

Tota AP (2009) The seduction of Brazil: the Americanization of Brazil during World War II. University of Texas Press, Austin

Vasquez M, Rocha C (2013) Introduction: Brazil in the new global cartography of religion. In: Rocha C, Vasquez M (eds) The diaspora of Brazilian religions. Brill, Boston, pp 1-42

Villa V (2020) Most states have religious exemptions to COVID-19 social distancing rules. Pew Research Center 11 June 2020. https://www.pewresearch.org/fact-tank/2020/04/27/most-states-have-religiousexemptions-to-covid-19-social-distancing-rules/

Volz B (2020) Worship from home: religious services to stream online during coronavirus pandemic. WKMG. 13 June 2020. https://www.clickorlando.com/news/local/2020/03/21/worship-from-home-religiousservices-to-stream-online-during-coronavirus-pandemic/

Wellman JK (2008) Evangelical vs. liberal: The clash of Christian cultures in the Pacific Northwest. Oxford University Press, New York

Wong JS (2018) Immigrants, evangelicals, and politics in an era of demographic change. Russell Sage Foundation, New York

Wuthnow R (1989) The restructuring of American religion. Princeton University Press, Princeton

Publisher's Note Springer Nature remains neutral with regard to jurisdictional claims in published maps and institutional affiliations. 